\title{
Abdominal palpation and percussion maneuvers do not affect bowel sounds
}

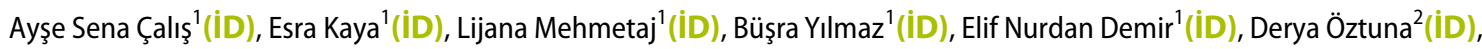
Evren Üstüner ${ }^{3}($ ID $)$, Halil Ibrahim Açar ${ }^{4}($ ID $)$, Serhat Tokgöz ${ }^{5}$ (ID), Muzaffer Akkoca ${ }^{5}$ (ID), Mehmet Ayhan Kuzư ${ }^{6}(i D)$

${ }^{1}$ Medical Student, Ankara University School of Medicine, Ankara, Turkey

2 Department of Biostatistics, Ankara University School of Medicine, Ankara, Turkey

${ }^{3}$ Department of Radiology, Ankara University School of Medicine, Ankara, Turkey

${ }^{4}$ Department of Anatomy, Ankara University School of Medicine, Ankara, Turkey

${ }^{5}$ Department of General Surgery, University of Health Sciences, Dışkapı Yıldırım Beyazıt Training and Research Hospital, Ankara, Turkey

${ }^{6}$ Department of General Surgery, Ankara University School of Medicine, Ankara, Turkey

\section{ABSTRACT}

Objective: Medical textbooks suggest that the frequency of bowel sounds may be altered by performing auscultation after palpation or percussion. We hypothesize that the frequency of bowel sounds is not affected by the order of abdominal examination.

Material and Methods: Both healthy volunteers $(n=80)$ and patients $(n=100)$ were enrolled in this crossover randomized study. Two different examination orders, one as inspection, palpation, percussion, auscultation (IPPA) and the other order as inspection, auscultation, palpation, percussion (IAPP) were used by two observers, one of which was blinded to the order of the physical examination and only performed auscultation. Bowel motilities of 40 participants were analyzed with duplex Doppler USG by a radiologist. The effects of changing the order of abdominal examination and palpationpercussion maneuvers on the frequency of bowel sounds were evaluated.

Results: Gender distribution was similar between the healthy patients and controls, and mean age of the entire study population was 47 (18-60) years. Differences between the mean bowel sound frequencies for abdominal examinations in order IPPA-IAPP versus IAPP-IPPA were evaluated for both healthy subjects and the patients. There were no differences between the first and second listening, nor were there differences between examinations performed in either order. Duplex Doppler Ultrasonographic (USG) assessments were performed on 20 healthy subjects and 20 patients before and after palpation and percussion; there were no statistically significant differences between the two listenings $(p=0.694)$.

Conclusion: According to both abdominal examinations and Doppler USG, the order of auscultation, whether performed before or after palpation or percussion, did not change the frequency of bowel sounds in this subject population.

Keywords: Abdominal examination, bowel sounds, physical examination order

Cite this article as: Calıs AS, Kaya E, Mehmetaj L, Y.lmaz B, Demir EN, Öztuna D, Üstüner E, Açar Hi, Tokgöz S, Akkoca M, Kuzu MA. Abdominal palpation and percussion maneuvers do not affect bowel sounds. Turk J Surg 2019; 35 (4): 309-313.

\section{Corresponding Author}

Muzaffer Akkoca

E-mail: muzafferakk@gmail.com

Received: 25.09.2018

Accepted: 27.03 .2019

Available Online Date: 16.12 .2019

OCopyright 2019 by Turkish Surgical Society Available online at www.turkjsurg.com

DOI: $10.5578 /$ turkjsurg. 4291

\section{INTRODUCTION}

History and physical examination are essential in treating patients across all medical fields. They are the most important and valuable stages in the practice of medicine. Further, they are often the first interaction between patient and doctor; if clinicians properly perform these steps, they can provide all of the information required for further diagnostics and appropriate therapies. Specifically, abdominal examination provides information regarding abdominal organs and structures (1-6).

It is recognized that auscultation provides information crucial to determining diseases of the respiratory and cardiovascular systems as well as the gastrointestinal tract. It was suggested early in the twentieth century that abdominal auscultation might indicate disorders of the gastrointestinal system (7). However, since then, little research has been done to define and specify the relationship between bowel sounds and their diagnostic value. In addition, there is uncertainty about the order in which auscultation should be performed during an ordinary abdominal examination. Classical textbooks claim that the accepted order of steps for an ordinary physical examination (i.e., inspection, palpation, percussion, and auscultation) should be changed for abdominal examinations because palpation or percussion before auscultation may affect the frequency of bowel sounds. In this study, we aimed to determine whether 
or not the order of the physical examination steps causes changes in the frequency of bowel sounds.

\section{MATERIAL and METHODS}

This study included healthy volunteers and patients admitted to the Ankara University Faculty of Medicine, Department of General Surgery. One hundred healthy volunteers and 120 eligible patients were included into this study between February 2014 and June 2014. Inclusion criteria for the healthy volunteers were as follows: not having any gastrointestinal system (GIS) disease, defecating a maximum of twice a day, not using any medication that affects the GIS, not having undergone any operation, and being between the ages of 18 and 60 years old. The same criteria were also applied to the patients admitted to the hospital for surgery because of cholelithiasis $(n=30)$, euthyroid multinodular goiter $(n=23)$, breast mass $(n=32)$ and inguinal hernia $(n=25)$. Duplex Doppler Ultrasonographic (USG) (Siemens G60, Siemens, Erlangen, Germany) assessments were performed on 20 healthy volunteers and 20 patients.

This study was approved by the Ankara University Faculty of Medicine "Clinical Research Ethics Committee" [Date: $27^{\text {th }}$ January 2014, Number: 02-60-14]. All subjects provided informed consent prior to the start of the study.

\section{Study Design}

This was a crossover randomized trial. Subjects (healthy volunteers $=80$; patients $=100$ ) were randomized via a random number generator program to receive the first abdominal examination in order inspection, palpation, percussion, auscultation (IPPA); healthy volunteers $=40$, patients $=50$ or order inspection, auscultation, palpation, percussion (IAPP); healthy volunteers = 40 , patients $=50$. This was followed by a "wash-out" period of one-hour and a crossover second examination in the other order. Physical examination was performed at least two and a half hours postprandially, and auscultation was performed for two minutes on each subject. For both the healthy controls and patients, an observer who was blinded to the physical examination order noted the bowel sound frequency.

Further, the effects of the order of physical examination were evaluated by abdominal ultrasonography (USG) and duplex Doppler USG in healthy volunteers $(n=20)$ and patients $(n=20)$.

\section{Abdominal Examination}

Subjects were examined in the supine position. Two third-year medical students who were trained in abdominal examination (both had previous experience on more than 50 healthy volunteers and patients) performed the examinations. One of the medical students ("the observer") performed the step-by-step physical examination in order IPPA or IAPP, but the other medical student ("the blind observer") joined only for the auscultation stage. The bowel sounds for each subject were listened to with Littman stethoscopes (3M, Littmann, USA) in one quadrant for two minutes by both the research student performing the whole exam and the blinded student.

\section{Doppler USG}

Duplex Doppler USG allowed for the visualization of bowel motility and at the same time allowed us to obtain the Doppler signals created by the motility of the bowel wall. Doppler signals were counted for one minute by a radiology specialist from Ankara University Faculty of Medicine Department of Radiology. The radiologist was blinded to the research protocol. The order of USG examination was as follows: first duplex Doppler USG palpation - percussion - second duplex Doppler USG.

\section{Sample Size}

The sample size was calculated based on the non-inferiority between order IPPA/IAPP and order IAPP/IPPA in terms of the mean bowel sound frequency. When the true difference between the means was assumed to be zero, the margin of non-inferiority was selected as -0.5 , and the significance level (a) of the test was 0.05. Group sample sizes of 51 and 51 achieved 81\% power to detect non-inferiority using a one-sided, two-sample t-test.

\section{Statistical Analysis}

The agreement between observers ("the observer" vs. "the blind observer") was calculated as the intraclass correlation coefficient (ICC) with a 95\% confidence interval (CI). The effect of the order of the abdominal physical examination on bowel sound frequency was evaluated by a repeated measures analysis of variance (ANOVA) and a paired t test. Descriptive statistics were presented as Mean \pm standard deviation (SD). Values of $p<0.05$ were considered statistically significant.

\section{RESULTS}

Abdominal examination analyses were performed on 80 healthy subjects and 100 patients. Genders were equally distributed among both healthy subjects and patients. Mean age and body mass index of the entire study population were 47 (18-60) years and 27 (21-42) BMI.

The agreement of auscultation between observers ("the observer" vs. "the blind observer") was determined to be good (ICC of 0.710 [95\% Cl: 0.612-0.784] for the first listening (a) and 0.773 [95\% Cl: 0.696-0.831] for the second listening (b).

The differences in mean bowel frequencies between the groups that were examined in order IPPA/IAPP versus order IAPP/IPPA were evaluated for both the healthy volunteers and the patients. Mean bowel sound frequencies were a little higher in subjects examined with the IAPP/IPAA, order, at both first and second listening, but the differences did not reach statistical significance (Table 1).

Duplex Doppler USG assessments were performed on 20 healthy subjects ( 10 females) and 20 patients ( 11 females). When Doppler USG assessments were evaluated for both groups, de- 
Table 1. Comparison of the groups in terms of listening findings

\begin{tabular}{|c|c|c|c|c|c|}
\hline Group & Listening & Order & Mean $\pm \mathrm{SD}^{\beta}$ & Factor ${ }^{*}$ & $\mathbf{p}$ \\
\hline \multirow[t]{4}{*}{ Patients $(n=100)$} & \multirow[t]{2}{*}{ First listening (a) } & IPPA/IAPP & $13.84 \pm 2.63$ & Listening & 0.973 \\
\hline & & IAPP/IPPA & $14.12 \pm 2.95$ & Order & 0.468 \\
\hline & \multirow[t]{2}{*}{ Second listening (b) } & IPPA/IAPP & $13.84 \pm 2.22$ & \multirow[t]{2}{*}{ Listening* Order } & \multirow[t]{2}{*}{0.973} \\
\hline & & IAPP/IPPA & $14.14 \pm 2.03$ & & \\
\hline \multirow[t]{4}{*}{ Healthy volunteers $(n=80)$} & \multirow[t]{2}{*}{ First listening (a) } & IPPA/IAPP & $14.85 \pm 3.26$ & Listening & 0.748 \\
\hline & & IAPP/IPPA & $15.73 \pm 3.78$ & Order & 0.068 \\
\hline & \multirow[t]{2}{*}{ Second listening (b) } & IPPA/IAPP & $14.38 \pm 3.48$ & \multirow[t]{2}{*}{ Listening* Order } & \multirow[t]{2}{*}{0.431} \\
\hline & & IAPP/IPPA & $15.93 \pm 3.45$ & & \\
\hline \multirow[t]{4}{*}{ Overall $(n=180)$} & \multirow[t]{2}{*}{ First listening (a) } & IPPA/IAPP & $14.29 \pm 2.95$ & Listening & 0.824 \\
\hline & & IAPP/IPPA & $14.83 \pm 3.42$ & Order & 0.065 \\
\hline & \multirow[t]{2}{*}{ Second listening (b) } & IPPA/IAPP & $14.08 \pm 2.85$ & \multirow[t]{2}{*}{ Listening* Order } & \multirow[t]{2}{*}{0.535} \\
\hline & & IAPP/IPPA & $14.93 \pm 2.88$ & & \\
\hline \multicolumn{6}{|c|}{$\begin{array}{l}\text { SD: Standard deviation. } \\
\text { * Factor corresponds to the variability sources in repeated measures ANOVA. The "listening","order" and "listening }{ }^{*} \text { order" refer to time effect, group effect, time* group } \\
\text { interaction effect, respectively. } \\
{ }^{*} \text { mean bowel sounds with in } 2 \text { min. }\end{array}$} \\
\hline
\end{tabular}

Table 2. The results of Doppler USG assessments by group

\begin{tabular}{|l|c|c|c|}
\hline Group & First listening $^{\mathbf{a}}$ & Second listening $^{\mathbf{a}}$ & $\mathbf{p}$ \\
\hline Patients $(\mathrm{n}=20)$ & $6.85 \pm 4.07[6(1-17)]$ & $6.85 \pm 4.72[6.5(0-20)]$ & 1.000 \\
\hline Healthy volunteers $(\mathrm{n}=20)$ & $8.15 \pm 3.56[8(3-18)]$ & $8.15 \pm 5.11[8(1-22)]$ & 1.000 \\
\hline a: Mean bowel sound assessed by Doppler USG within one minute.
\end{tabular}

scriptive statistics \{mean \pm SD [median (minimum-maximum)] of the first and second listening were $7.50 \pm 3.83$ [7 (1-18)] and $7.50 \pm 4.90$ [7 (0-22)], respectively $(p=0.694)$. Group-based results are presented in Table 2.

\section{DISCUSSION}

Despite developing technologies, physical examination still plays the most important role in the diagnosis and treatment of the diseases today. It is accepted that all laboratory, imaging, and biological tests only make sense when performed in conjunction with physical examination. In other words, laboratory and imaging techniques are only of value in cases where there is accordance between the tests and clinical physical examination.

Historically, physical examinations were performed in the order of inspection, palpation, percussion, and auscultation. However, the order for abdominal physical examination has recently been changed to inspection, auscultation, palpation, and percussion since it has been suggested that performing auscultation prior to palpation and percussion maneuvers may prevent possible effects on bowel sounds. Most of the medical faculties all over the world currently use and teach this order as a standard of care.

Reviewing the literature, we realized that there were scarce and inconsistent publications on the value of auscultation. Moreover, none investigated the relationship between the order of the physical examination and bowel motility. Our current randomized crossover study revealed that palpation and percussion maneuvers had no negative impact on the results obtained during auscultation in healthy subjects and patients without GIS disease. In addition, the results of the Duplex-Doppler ultrasonography, an acceptable method for evaluating intestinal motility (8), also supported our findings. Thus, our results indicate that it is not the order of physical examination that is crucial step for confirming the diagnosis but precise history and physical examination.

Although the auscultation of bowel sounds is considered an essential component of an adequate physical examination, its clinical value remains largely unstudied and subjective. It is now more than 100 years since Cannon described the rhythmic bowel sounds and their possible relationship with intestinal disorders (7), however there is little published information regarding the value of auscultation, and contradictory findings exist in the literature (9). Gu et al. (10) have concluded that the auscultation of bowel sounds is useful, especially in detecting ileus with a high positive predictive value. Similarly, Sugrue et al. (11) have found that the sound duration, interval and amplitude all significantly increased in bowel obstruction when compared to control subjects. In contrast, Ching \& Tan have assessed the spectral analysis of bowel 
sounds in intestinal obstruction using an electronic stethoscope. They found that bowel sound characteristics were not different among patients with acute, subacute or no intestinal obstruction using the commonly compared parameters including sound duration, sound-to-sound interval, and dominant and peak frequencies (12). In another study, the authors concluded that auscultation of bowel sounds is not a useful clinical practice when differentiating patients with normal versus pat hologic bowel sounds (13). This has been echoed in other studies as well (14-16).

Furthermore, peristaltic movements, and associated bowel sounds, can vary with the course of disease. For example, in diarrhea, peristaltic movements increase occasionally, but return to normal after defecation. In cases of bowel obstruction, bowel motility increases while trying to overcome the obstacle, but after a while, there is a reduction or a stoppage of bowel motility due to tired intestinal muscles and atony. Whereas further research needs to be done to clarify the clinical value of bowel sounds, it nevertheless remains an integral part of the physical exam as taught in medical schools.

The major disadvantage of this prospective randomized study is the lack of underlying GIS disease in the patients included in this study. We could not assess the importance of changing the order of physical examination in patients with intestinal obstruction since crossover randomization in such patients would be inappropriate.

\section{CONCLUSION}

The results of this study indicate that the order of physical examination does not make a significant difference in terms of bowel motility. Therefore, the order of physical examination is not important. This information will be helpful to both the tutors of medicine and the clinicians who perform abdominal examinations.

Ethics Committee Approval: This study was approved by the Ankara University Faculty of Medicine "Clinical Research Ethics Committee" [Date: 27th January 2014, Number: 02-60-14]. All subjects provided informed consent prior to the start of the study.

Informed Consent: Written informed consent was obtained from patients who participated in this study.

Peer-review: Externally peer-reviewed.

Author Contributions: Concept - A.S.Ç., M.A.K.; Design - A.S.Ç., E.K., L.M., M.A.K.; Supervision - A.S.Ç., B.Y., E.N.D., M.A.K.; Resource - A.S.Ç., H.I.A., M.A.K.; Materials - A.S.Ç., E.K., L.M., B.Y., E.N.D., E.Ü., H.I.A., M.A.K.; Data Collection and/ or Processing - A.S.C.., E.K., L.M., B.Y., E.N.D., D.Ö., E.Ü., H.I.A.; Analysis and/or In- terpretation - A.S.Ç., D.Ö., E.Ü., H.I.A., S.T., M.A., M.A.K.; Literature Search - A.S.Ç., E.Ü., H.I.A., M.A.K.; Writing Manuscript - All of authors; Critical Reviews - A.S.Ç., E.Ü., H.I.A., S.T., M.A., M.A.K.

Conflict of Interest: The authors have no conflicts of interest to declare.

Financial Disclosure: The authors declared that this study has received no financial support.

\section{REFERENCES}

1. Bickley, Lynn S. Bates' Guide to Physical Examination and History-taking. $17^{\text {th }}$ ed. Philadelphia: Wolters Kluwer Health/Lippincott Williams and Wilkins, 2013:4-23.

2. Goldman L, Schafer Al. Goldman's Cecil Medicine. 24th ed. Philadelphia: Elsevier/Saunders, 2012:22-7.

3. Seidel H, Ball J, Dains J, Solomon S, Stewart R. Mosby's Guide to Physical Examination. $7^{\text {th }}$ ed. St. Louis, Missouri: Elsevier/Mosby, 2011:47-51.

4. Hira HS. Clinical Examination; A Practical Guide in Medicine. $1^{\text {st }} \mathrm{ed}$. Jaypee Brothers Medical Publishers, 2011:195-210.

5. Abbott H, Baithwaite W, Ranson M, Blood M. Clinical Examination Skills for Healthcare Professionals. $1^{\text {st }}$ ed. M\&K Update, 2014;chapter 4:35-42.

6. Kauffman M. History and Physical Examination a Common Sense Approach. Burlington, MA: Jones \& Bartlett Learning, 2014;Chapter 12:145-59.

7. Cannon WB. Auscultation of the rhythmic sounds produced by the stomach and intestines. Am J Physiol 1905;14:339-53.[CrossRef]

8. Ferguson CM. Inspection, auscultation, palpation, and percussion of the abdomen. In: Walker HK, Hall WD, Hurst JW (eds). Clinical Methods: The History, Physical, and Laboratory Examinations. $3^{\text {rd }}$ ed. Philadelphia: Butterworth, 1990; chapter 93.

9. Gimondo P, Mirk P. A new method for evaluating small intestinal motility using duplex doppler sonography. Am J Roentgenol 1997;168:18792.[CrossRef]

10. GuY, Lim HJ, Moser MAJ. How useful are bowel sound in assessing the abdomen? Digestive Surgery 2010;27:422-6.[CrossRef]

11. Sugrue $M$, Redtern M. Computerized phonoenterography the clinical investigation of a new system. J Clin Gastroenterol 1994;18:139-44. [CrossRef]

12. Ching S, Tan YK. Spectral analysis of bowel sounds in intestinal obstruction using an electronic stethoscope. World I Gastroenterol 2012;18(33):4585-92.[CrossRef]

13. Felder S, Margel D, Murrell Z, Fleshner P. Usefulness of bowel sound auscultation: a prospective evaluation. J Surg Edu 2014;71(5):768-73. [CrossRef]

14. Fairclough PD, Silk DBA. Gastrointestinal disease. In: Kumar P, Clark M (eds). Kumar and Clark's Clinical Medicine. $7^{\text {th }}$ ed. Edinburgh: Saunders, 2009:241-318.

15. Harris S, Naina HV, Kuppachi S. Look, feel, listen or look, listen, feel? Am J Med 2007;120(2):3.[CrossRef]

16. West M, Klein MD. Is abdominal auscultation important? Lancet 1982;2(8310):1279.[CrossRef] 


\section{ORIJINAL ÇALIŞMA-ÖZET}

Turk J Surg 2019; 35 (4): 309-313

\section{Abdominal palpasyon ve perküsyon manevraları bağırsak seslerini etkilemez}

Ayşe Sena Çalış ${ }^{1}$, Esra Kaya ${ }^{1}$, Lijana Mehmetaj ${ }^{1}$, Büşra Yılmaz ${ }^{1}$, Elif Nurdan Demir ${ }^{1}$, Derya Öztuna ${ }^{2}$, Evren Üstüner ${ }^{3}$, Halil Ibrahim Açar ${ }^{4}$, Serhat Tokgöz ${ }^{5}$, Muzaffer Akkoca ${ }^{5}$, Mehmet Ayhan Kuzu ${ }^{6}$

${ }^{1}$ Ankara Üniversitesi Tıp Fakültesi, Öğrenci Ankara, Türkiye

${ }^{2}$ Ankara Üniversitesi Tıp Fakültesi, Biostatistik Anabilim Dalı, Ankara, Türkiye

${ }^{3}$ Ankara Üniversitesi Tıp Fakültesi, Radyoloji Anabilim Dalı, Ankara, Türkiye

${ }^{4}$ Ankara Üniversitesi Tıp Fakültesi, Anatomi Anabilim Dalı, Ankara, Türkiye

${ }^{5}$ Sağılık Bilimleri Üniversitesi Dışkapı Yıldııım Beyazıt Eğitim ve Araştırma Hastanesi, Genel Cerrahi Kliniği Ankara, Türkiye

${ }^{6}$ Ankara Üniversitesi Tıp Fakültesi, Genel Cerrahi Anabilim Dalı, Ankara, Türkiye

\section{ÖZET}

Giriş ve Amaç: Tıbbi ders kitapları, fizik muayenede oskültasyonun palpasyon veya perküsyondan sonra yapıldığında bağırsak seslerinin sıklığının değişebileceğini öne sürmektedir. Bu çalışmanın amacı, abdominal muayene sırasının bağırsak seslerinin sıklığını etkileyip etkilemediğini belirlemektir.

Gereç ve Yöntem: Bu randomize çalışmaya hem sağlıklı gönüllüler $(n=80)$ hem de hastalar $(n=100)$ dahil edildi. Biri inspeksiyon, palpasyon, perküsyon, oskültasyon (IPPA), diğeri inspeksiyon, oskültasyon, palpasyon, perküsyon (IAPP) olmak üzere iki farklı muayene sıralaması, biri fizik muayene sırasına göre kör olan ve sadece oskültasyon yapan iki gözlemci tarafından kullanıldı. Kırk katılımcının bağırsak hareketleri, bir radyolog tarafından dupleks Doppler ultrasonografi ile analiz edildi. Abdominal muayene sırasındaki değişiklik ve palpasyon perküsyon manevralarının bağırsak seslerinin sıklığı üzerindeki etkileri değerlendirildi.

Bulgular: Her iki grupta cinsiyet dağılımı benzerdi ve tüm çalışma popülasyonunun yaş ortalaması 47 (18-60) idi. Ortalama bağırsak ses frekansları farklı karın muayene sıraları olan sağlıklı ve hasta bireylerde değerlendirildi. Illk ve ikinci dinleme arasında hiçbir fark yoktu. Dupleks Doppler USG değerlendirmeleri 20 sağlıklı bireyde ve 20 hasta üzerinde palpasyon ve perküsyon öncesi ve sonrası yapıldı; iki grup arasında istatistiksel olarak anlamlı fark yoktu $(p=0.694)$.

Sonuç: Değerlendirilen gruplarda abdominal muayeneye ve Doppler USG'ye göre, oskültasyonun palpasyon ve perküsyondan önce veya sonra yapılmasının bağırsak seslerinin sıklığını değiştirmediği görüldü.

Anahtar Kelimeler: Karın muayenesi, bağırsak sesleri, Fiziksel muayene sırası

Doi: $10.5578 /$ turkjsurg.4291 